\title{
Occurrence of eggs and oocysts of gastrointestinal parasites in passerine birds kept in captivity in Para State, Brazil
}

\author{
Ocorrência de ovos e oocistos de parasitos gastrointestinais em aves \\ Passeriformes mantidas em cativeiro no estado do Pará, Brasil
}

\author{
Paulo Cesar Magalhães-Matos ${ }^{I}$ Michele Bahia do Vale Silva ${ }^{I}$ Paulo Geovani Silva Souza \\ Danillo Henrique da Silva Lima ${ }^{I}$ Rodrigo de Morais ${ }^{I}$ Diana Maria de Farias ${ }^{I}$ \\ Laís Cristina Oliveira Alvarenga' ${ }^{I}$ Áurea Martins Gabriel ${ }^{\text {II }}$ Wanessa Batista Lima Oliveira ${ }^{\text {III }}$ \\ Gustavo Góes-Cavalcante ${ }^{I}$ Alessandra Scofield ${ }^{I^{*}}$
}

\section{ABSTRACT}

The objective of this study was to detect helminth eggs and protozoan oocysts in samples of feces from birds of the order Passeriformes in Para State, Brazil. Fecal samples were collected individually from 403 passerine birds seized and kept in captivity in Para State. Samples were processed by the double centrifugation technique in saturated sucrose solution and the coccidial oocystpositive samples were submitted to sporulation in potassium dichromate $2.0 \%$. Helminth eggs and/or protozoan oocysts were observed in $43.18 \%$ (174/403) of the fecal samples examined. Coccidial oocysts were detected in $93.68 \%$ (163/174) of the positive samples, whereas helminth eggs were observed in 10.34\% (18/174) of the positive samples. Oocyst sporulation occurred in $43.56 \%$ (71/163) of the samples, and only Isospora spp. oocysts were detected. Nematode eggs of the superfamilies Trichostrongyloidea $(4.60 \% ; 8 / 174)$, Ascaridoidea $(0.57 \% ; 1 / 174)$, and Trichuroidea $(0.57 \% ; 1 / 174)$ were diagnosed in the positive samples. Cestoda eggs were diagnosed in $2.87 \%$ (5/174), whereas Trematoda eggs were detected in $2.30 \%$ (4/174) of positive samples. Passerine birds seized and kept in captivity in the visited local presented parasitism by intestinal helminths and protozoan, with a predominance of infection with coccidia of the gender Isospora.

Key words: passerine birds, endoparasites, coccidia, helminths, Brazilian Amazon.

RESUMO

O objetivo do presente estudo foi detectar ovos de helmintos e oocistos de protozoários em amostras de fezes de aves da ordem Passeriformes no estado do Pará, Brasil. Amostras de fezes foram coletadas individualmente de 403 aves Passeriformes oriundas de apreensão e mantidas em cativeiro no estado do Pará. As amostras foram processadas usando a técnica de dupla centrifugação em solução saturada de sacarose e as amostras positivas para oocistos de coccídios foram submetidas à esporulação em dicromato de potássio 2,0\%. Ovos de helmintos el ou oocistos de protozoários foram observados em 43,18\% (174/403) das amostras fecais examinadas. Oocistos de coccídios foram detectados em 93,68\% (163/174) das amostras positivas, enquanto que ovos de helmintos foram observados em 10,34\% (18/174). A esporulação de oocistos ocorreu em 43,56\% (71/163) das amostras, e somente oocistos de Isospora spp. foram detectados. Ovos de nematódeos das Superfamílias Trichostrongyloidea $(4,60 \% ; 8 / 174)$, Ascaridoidea $(0,57 \%$; 1/174) e Trichuroidea $(0,57 \% ; 1 / 174)$ foram diagnosticados nas amostras positivas. Ovos de Cestoda foram diagnosticados em 2,87\% (5/174), enquanto que ovos de Trematoda foram detectados em 2,30\% (4/174) das amostras positivas. Aves Passeriformes oriundas de apreensão e mantidas em cativeiro nas áreas visitadas estavam parasitadas por helmintos e protozoários, predominando a infecção por coccídios do gênero Isospora.

Palavras-chave: pássaros, endoparasitos, coccídios, helmintos, Amazônia Brasileira.

\section{INTRODUCTION}

Brazil, Colombia, and Peru are considered to have the largest avian fauna diversity in the world, and South America was thus entitled the "Continent of Birds" (PIACENTINI et al., 2015; REMSEN et al., 2016). The most recent list of Brazilian ornithological fauna included 1,919 species (PIACENTINI et al., 2015), and 993 species are recorded in the Brazilian Amazon Biodiversity Census (MPEG, 2016). Among

\footnotetext{
Instituto de Medicina Veterinária, Universidade Federal do Pará (UFPA), BR-316, Km 61, 68740-080, Castanhal, PA, Brasil. E-mail: ascofield@ufpa.br. "Corresponding author.

IIInstituto de Higiene e Medicina Tropical, Universidade Nova de Lisboa (UNL), Lisboa, Portugal.

III Independent biologist, Ananindeua, PA, Brasil.
} 
birds, the order Passeriformes has a great importance due to its diversity, which corresponds to about $56 \%$ of total species in Brazil (PIACENTINI et al., 2015).

Parasitic diseases are among the major health problems affecting passerine birds. Such diseases can cause subclinical alterations or even death of birds subjected to stress, recently introduced or kept in high-population density precincts. Although little is known about parasitic infection rates of passerines in different regions of Brazil, it is known that helminthiasis and coccidiosis often affect birds in captivity (FIGUEROA-LYRA et al., 2002; BERTO et al., 2011). Therefore, diagnostic studies on endoparasites both extend knowledge about the epidemiology of gastrointestinal diseases and serve as a basis to implement an adequate health management for wild birds kept in captivity (GUIMARÃES, 2007). Therefore, the objective of this study was to detect helminth eggs and protozoan oocysts in samples of feces from birds of the order Passeriformes seized and kept in captivity in the Para State, Brazil.

\section{MATERIALS AND METHODS}

Animals and study area

Four hundred and three fecal samples were collected from birds of the order Passeriformes of the families Cardinalidae $(n=3)$, Corvidae $(n=1)$, Cotingidae $(n=3)$, Estrildidae $(n=1)$, Icteridae $(n=19)$, Pipridae $(n=1)$, Thraupidae $(n=352)$, and Turdidae $(n=23)$. Birds were identified based on the Field Guide of Birds in Brazil (SIGRIST, 2009) and List of Birds in Brazil (PIACENTINI et al., 2015). Passerine birds were seized by the Brazilian Institute of the Environment and Natural Renewable Resources in the interior and capital of Para State, Brazil. These birds were transported to the Mangal das Garças Environmental Park (S 01²7'56.0”, W 48³0'18’), in the city of Belém, and Adhemar Monteiro Zoo and Botanical Park (S 144'45.5”,W 4703'27.1”), Capitão Poço city, Para State. Fecal samples were also obtained from the Albatroz commercial breeding (S 01²7'19.9', W 48²7'53.6”) in Belém city.

Collection and processing of biological samples From March 2009 to January 2012, 403 fecal samples from birds were individually collected from the cages floor early in the morning, placed in labeled plastic containers, and processed by the double centrifugation technique in saturated sucrose solution (MONTEIRO, 2010). After centrifugation (Excelsa ${ }^{\circledR}$ II 206 BL centrifuge), the supernatant was analyzed between slide and cover slip in an optical microscope $\left(\right.$ Nikon $^{\circledR}$ 50i; objectives: 10x, 40x, and 100x). Coccidial oocyst-positive samples were immersed in potassium dichromate $\left(\mathrm{K}_{2} \mathrm{Cr}_{2} \mathrm{O}_{7}\right)$ $2 \%$ solution and maintained at room temperature for seven days or until oocyst sporulation (DUSZYNSKI \& WILBER, 1997). After analysis, all results were sent to the respective sample collection locations for treatment and adequacy of sanitary management.

\section{RESULTS AND DISCUSSION}

Occurrence of helminth and oocyst eggs of gastrointestinal protozoans was observed in passerine birds kept in captivity in the Brazilian Amazon (Table 1; Figure 1A-H), including in species such as Cyanoloxia rothschildii, Paroaria gularis, and Tangara episcopus, whose distribution is restricted to the Amazon biome (SIGRIST, 2009). Infections caused by gastrointestinal parasites are considered a risk to avian health, especially those under stress conditions, inadequate management, and poor nutrition in captivity (FIGUEIROA-LYRA et al., 2002; GUIMARÃES, 2007). Therefore, recently seized or imported birds deserve a closer monitoring regarding anti-parasitic diagnosis and treatment, as these birds are more susceptible to these infections (OGLESBEE, 2008).

Helminth eggs and/or protozoan oocysts were observed in $43.18 \%(174 / 403)$ of the fecal samples (Table 1). Coccidial oocysts (Figure 1A-C) were detected in $93.68 \%(163 / 174)$ of the positive samples, whereas helminth eggs (Figure 1D-H) were observed in $10.34 \%$ (18/174) of these samples. Oocyst sporulation occurred in $43.56 \%(71 / 163)$ of samples and only Isospora spp. oocysts were detected (Table 1; Figure 1A-C). Nematode eggs were diagnosed in positive samples of the superfamilies Trichostrongyloidea (4.60\%; 8/174; Figure 1D), Ascaridoidea (0.57\%; $1 / 174$; Figure $1 \mathrm{E})$, and Trichuroidea $(0.57 \% ; 1 / 174$; Figure $1 \mathrm{~F}$ ). Cestoda eggs (Figure $1 \mathrm{G}$ ) were diagnosed in $2.87 \%(5 / 174)$, whereas Trematoda eggs (Figure $1 \mathrm{H})$ were detected in $2.30 \%$ (4/174) of positive samples.

Regarding parasitism relative to the passerine species, nematode eggs of the superfamily Trichostrongyloidea were observed in fecal samples from S. angolensis (1.06\%; 3/282), Sporophila maximiliani $(5.26 \% ; 1 / 19)$, Sporophila americana (28.57\%; 2/7), T. episcopus $(33.33 \% ; 1 / 3)$, and the only sample from Sporophila plumbea. Nematode eggs of the superfamily Ascaridoidea (4.35\%; 1/23) were observed and helminth eggs of the superfamily Trichuroidea $(4.35 \% ; 1 / 23)$ were also diagnosed in Turdus sp. fecal samples. Typical Cestoda eggs were observed in fecal samples from Paroaria gularis 
Table 1 - Results of coproparasitological analysis in species of passerine birds.

\begin{tabular}{|c|c|c|c|c|c|c|}
\hline \multirow[b]{2}{*}{ Families } & \multirow[b]{2}{*}{ Taxon } & \multirow{2}{*}{$\begin{array}{l}\text { Number } \\
\text { of } \\
\text { samples }\end{array}$} & \multicolumn{4}{|c|}{--_---Samples positive for oocysts and/or helminth eggs (\%)--_-_-_- } \\
\hline & & & $\begin{array}{l}\text { Coccidial oocysts } \\
\text { (sporulated and } \\
\text { not sporulated) }\end{array}$ & $\begin{array}{l}\text { Sporulated } \\
\text { Isosporaspp. oocysts }\end{array}$ & Helminth eggs & $\begin{array}{l}\text { Total of positive } \\
\text { samples }\end{array}$ \\
\hline & Sporophila angolensis & 282 & $37.23 \%(105 / 282)$ & $15.6 \%(44 / 282)$ & $1.06 \%(3 / 282)$ & $37.59 \%(106 / 282)$ \\
\hline & Sporophila maximiliani & 19 & $63.15 \%(12 / 19)$ & $42.1 \%(8 / 19)$ & $5.26 \%(1 / 19)$ & $68.42 \%(13 / 19)$ \\
\hline & Sporophila lineola & 8 & $62.5 \%(5 / 8)$ & $0 \%(0 / 8)$ & $0 \%(0 / 8)$ & $62.5 \%(5 / 8)$ \\
\hline & Sporophila americana & 7 & $28.57 \%(2 / 7)$ & $28.57 \%(2 / 7)$ & $28.57 \%(2 / 7)$ & $57.14 \%(4 / 7)$ \\
\hline & Paroaria gularis & 7 & $57.14 \%(4 / 7)$ & $28.57 \%(2 / 7)$ & $14.29 \%(1 / 7)$ & $71.43 \%(5 / 7)$ \\
\hline & Tangara episcopus & 5 & $60 \%(3 / 5)$ & $60 \%(3 / 5)$ & $0 \%(0 / 5)$ & $60 \%(3 / 5)$ \\
\hline & Tangara cayana & 4 & $50 \%(2 / 4)$ & $50 \%(2 / 4)$ & $25 \%(1 / 4)$ & $75 \%(3 / 4)$ \\
\hline & Sporophila minuta & 4 & $25 \%(1 / 4)$ & $0 \%(0 / 4)$ & $0 \%(0 / 4)$ & $25 \%(1 / 4)$ \\
\hline \multirow[t]{9}{*}{ Thraupidae } & Dolospingus fringilloides & 4 & $100 \%(4 / 4)$ & $0 \%(0 / 4)$ & $0 \%(0 / 4)$ & $100 \%(4 / 4)$ \\
\hline & Saltator similis & 3 & $33.33 \%(1 / 3)$ & $0 \%(0 / 3)$ & $0 \%(0 / 3)$ & $33.33 \%(1 / 3)$ \\
\hline & Lanio surinamus & 2 & $100 \%(2 / 2)$ & $50 \%(1 / 2)$ & $0 \%(0 / 2)$ & $100 \%(2 / 2)$ \\
\hline & Sicalis flaveola & 2 & $100 \%(2 / 2)$ & $100 \%(2 / 2)$ & $50 \%(1 / 2)$ & $100 \%(2 / 2)$ \\
\hline & Sporophila schistacea & 1 & $100 \%(1 / 1)$ & $0 \%(0 / 1)$ & $0 \%(0 / 1)$ & $100 \%(1 / 1)$ \\
\hline & Sporophila plumbea & 1 & $100 \%(1 / 1)$ & $0 \%(0 / 1)$ & $100 \%(1 / 1)$ & $100 \%(1 / 1)$ \\
\hline & Cyanicterus cyanicterus & 1 & $100 \%(1 / 1)$ & $0 \%(0 / 1)$ & $0 \%(0 / 1)$ & $100 \%(1 / 1)$ \\
\hline & Cissopis leverianus & 1 & $0 \%(0 / 1)$ & $0 \%(0 / 1)$ & $0 \%(0 / 1)$ & $0 \%(0 / 1)$ \\
\hline & Saltator maximus & 1 & $0 \%(0 / 1)$ & $0 \%(0 / 1)$ & $0 \%(0 / 1)$ & $0 \%(0 / 1)$ \\
\hline \multirow[t]{4}{*}{ Turdidae } & Turdus spp. & 23 & $30.43 \%(7 / 23)$ & $8.7 \%(2 / 23)$ & $26.09 \%(6 / 23)$ & $47.83 \%(11 / 23)$ \\
\hline & Icterus jamacaii & 5 & $20 \%(1 / 5)$ & $20 \%(1 / 5)$ & $0 \%(0 / 5)$ & $20 \%(1 / 5)$ \\
\hline & Gymnomystax mexicanus & 4 & $50 \%(2 / 4)$ & $25 \%(1 / 4)$ & $0 \%(0 / 4)$ & $50 \%(2 / 4)$ \\
\hline & Gnorimopsar chopi & 3 & $66.66 \%(2 / 3)$ & $33.33 \%(1 / 3)$ & $33.33 \%(1 / 3)$ & $66.66 \%(2 / 3)$ \\
\hline \multirow[t]{4}{*}{ Icteridae } & Icterus chrysocephalus & 3 & $66.66 \%(2 / 3)$ & $33.33 \%(1 / 3)$ & $0 \%(0 / 3)$ & $66.66 \%(2 / 3)$ \\
\hline & Cacicus cela & 2 & $50 \%(1 / 2)$ & $0 \%(0 / 2)$ & $0 \%(0 / 2)$ & $50 \%(1 / 2)$ \\
\hline & Molothrus oryzivorus & 1 & $0 \%(0 / 1)$ & $0 \%(0 / 1)$ & $0 \%(0 / 1)$ & $0 \%(0 / 1)$ \\
\hline & Cacicus haemorrhous & 1 & $0 \%(0 / 1)$ & $0 \%(0 / 1)$ & $0 \%(0 / 1)$ & $0 \%(0 / 1)$ \\
\hline Cardinalidae & Cyanoloxia rothschildii & 3 & $33.33 \%(1 / 3)$ & $0 \%(0 / 3)$ & $33.33 \%(1 / 3)$ & $66.66 \%(2 / 3)$ \\
\hline Estrildidae & Estrilda astrild & 1 & $0 \%(0 / 1)$ & $0 \%(0 / 1)$ & $0 \%(0 / 1)$ & $0 \%(0 / 1)$ \\
\hline Pipridae & Pipra fasciicauda & 1 & $0 \%(0 / 1)$ & $0 \%(0 / 1)$ & $0 \%(0 / 1)$ & $0 \%(0 / 1)$ \\
\hline Cotingidae & Procnias averano & 3 & $33.33 \%(1 / 3)$ & $33.33 \%(1 / 3)$ & $0 \%$ & $33.33 \%(1 / 3)$ \\
\hline Corvidae & Cyanocorax cyanopogon & 1 & $0 \%(0 / 1)$ & $0 \%(0 / 1)$ & $0 \%(0 / 1)$ & $0 \%(0 / 1)$ \\
\hline TOTAL & & 403 & $40.45 \%(163 / 403)$ & $17.62 \%(71 / 403)$ & $4.47 \%(18 / 403)$ & $43.18 \%(174 / 403)$ \\
\hline
\end{tabular}

(14.29\%; 1/7), Turdus spp. (13.04\%; 3/23), and Tangara cayana $(25 \% ; 1 / 4)$, and trematode eggs were diagnosed in samples from Turdus sp. $(8.7 \% ; 2 / 23)$, Gnorimopsar chopi $(33.33 \%$; 1/3), and Sicalis flaveola (50\%; 1/2).

Regarding the type of parasitism, simple parasitism was observed in $95.98 \%(167 / 174)$ of the positive fecal samples. Coparasitism by coccidial oocysts and helminth eggs was observed in $4.02 \%$ (7/174) of the parasitized passerine birds. This coparasitism was diagnosed in fecal samples from Turdus spp. $(\mathrm{n}=2), S$. angolensis $(\mathrm{n}=2), \boldsymbol{S}$. flaveola $(\mathrm{n}=1), \boldsymbol{G}$. chopi $(\mathrm{n}=1)$, and $S$. plumbea $(\mathrm{n}=1)$. Parasitism by more than one class of helminths was diagnosed in one fecal sample from Turdus sp., and nematode (superfamily Trichuroidea) and trematode eggs were observed.

Most infected birds presented simple parasitism by coccidial oocysts, with a predominance of Isospora spp. oocysts, similar to the data obtained by BERTO et al. (2011), who showed that most coccidia infecting passerine birds are species of the genus Isospora, but Eimeria species also occurred although with a lower frequency. Our results are also consistent with observations in Saltator similis in captivity, in Valença, Rio de Janeiro State, Brazil, and according to VASCONCELOS et al. (2013) Isospora 


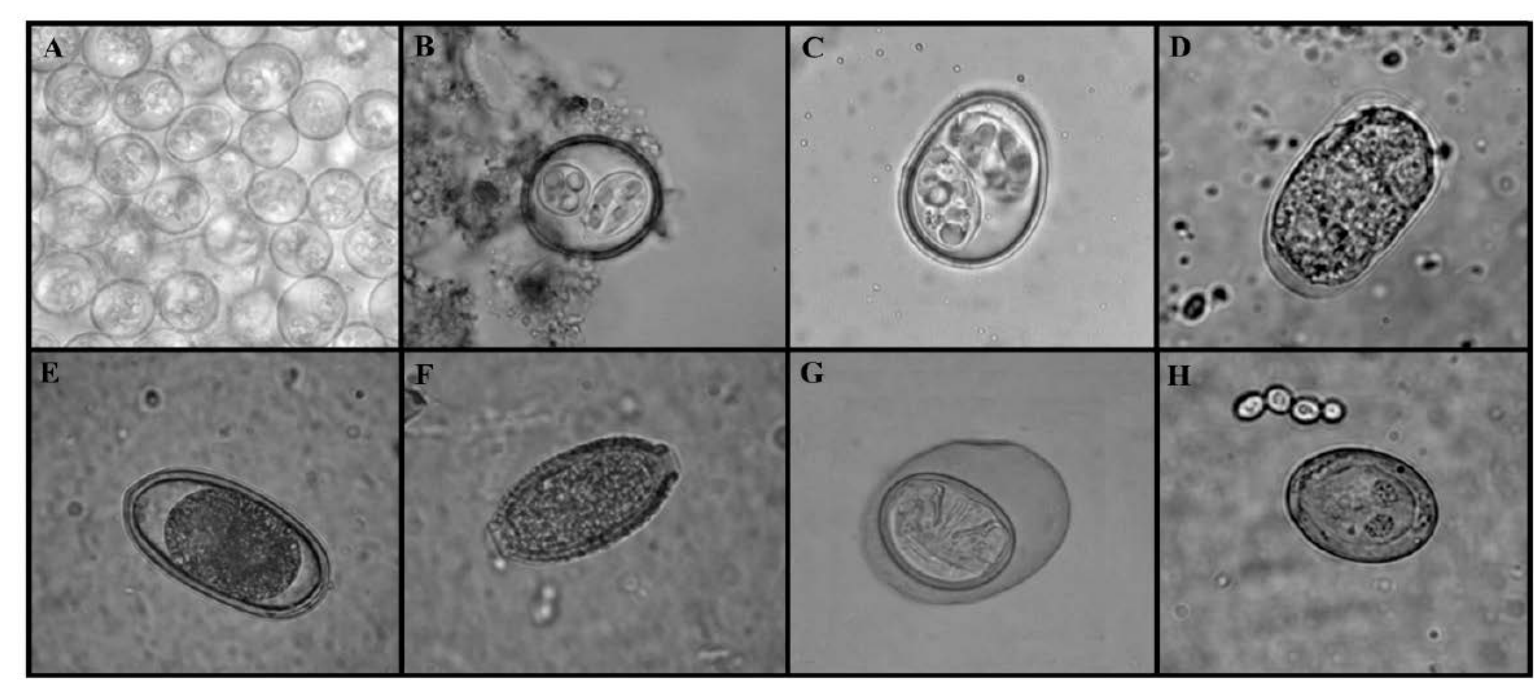

Figure 1 - Coccidial oocysts and helminth eggs diagnosed in fecal samples from passerine birds: A) Isospora spp. oocysts in feces from Sporophila angolensis (40x); B) Isospora sp. oocyst in feces from Icterus jamacaii (100x); C) Isospora sp. oocyst in feces from Tangara episcopus (100x); D) Nematode egg of the superfamily Trichostrongyloidea in feces from Sporophila maximiliani (40x); E) Nematode egg of the superfamily Ascaridoidea in feces from Turdus spp. (40x); F) Nematode egg of the superfamily Trichuridoidea in feces from Turdus spp. (40x); G) Cestoda egg in feces from Turdus spp. (40x); H) Trematoda egg in feces from Sicalis flaveola (40x).

spp. oocysts $(90 \%)$ were detected in animals with moderate to high infection rate.

Intestinal coccidial infections can also be considered frequent in free-living passerine birds. COSTA et al. (2010) detected coccidial oocyst-positive fecal samples $(58.66 \%)$ in birds captured in Seropedica city, Rio de Janeiro State, and most birds were of the order Passeriformes. These data are similar to those obtained in present study with captive animals, in which high occurrence of infection by coccidial oocysts was observed.

In the present study, a large number of Isospora spp. oocysts (Figure 1A) was detected in some fecal samples although helminth eggs and protozoan oocysts quantification was not performed. The high parasitism as observed in these animals may have occurred due to stress during seizure and captivity, as birds are usually kept in small cages. According to GILL \& PAPERNA (2008), free-living birds are able to control coccidial infection, not manifesting clinical signs suggestive of the disease. However, these birds succumb to infection and present changes in the social and reproductive behavior, diarrhea, weight loss, and even death when subjected to capture stress or captivity. Although helminth eggs have occurred in few fecal samples, a diversity these eggs was observed. In Turdus spp., e.g., trematode, cestode, and nematode eggs of the superfamilies Ascaridoidea and Trichuroidea were found. In Pernambuco State, Brazil, FIGUEIROALYRA et al. (2002) conducted a survey of endoparasites in captive wild birds using sedimentation and flotation techniques and reported positive samples (46.7\%; $320 / 685)$. In passerine birds of the family Icteridae, the authors diagnosed Cestoda eggs, whereas in birds of the family Cotingidae parasitism was not observed. In Para State, Cestoda eggs were also observed in fecal samples from the icteride G. chopi, and presence of Isospora sp. oocysts was also detected in samples from the cotingide Procnias averano.

It was also observed that the species $\boldsymbol{S}$. maximiliani and $\boldsymbol{P}$. averano, which are threatened with extinction in the Brazilian wildlife (MMA, 2003), were reported to be infected with Isospora spp. oocysts, whereas helminth eggs from the superfamily Trichostrongyloidea were found only in $\boldsymbol{S}$. maximiliani. The results of the present study reinforce the importance of diagnosis for the control of coccidiosis and helminthiasis in birds seized and/ or kept in captivity. Based on knowledge about these infections, is possible to establish appropriate treatment and management, in order to improve the sanitary conditions and survival of captive birds.

\section{CONCLUSION}

Passerine birds seized and kept in captivity in the visited cities presented parasitism by intestinal helminths and protozoan, with a predominance of infection with coccidia of the gender Isospora.

Ciência Rural, v.46, n.12, dez, 2016. 


\section{ACKNOWLEDGEMENTS}

We thank the Pro-Rector of Extension (PROEX) Universidade Federal do Para (UFPA), for the financial support. Authors are especially grateful for the institutional assistance provided at the Mangal das Garças Environmental Park, Adhemar Monteiro Zoo and Botanical Park, and Albatroz commercial breeding.

\section{BIOETHICS AND BIOSSECURITY COMMITTEE APPROVAL}

Authors' declaration

We, authors of the article entitled "Occurrence of eggs and oocysts of gastrointestinal parasites in passerine birds kept in captivity in Para State, Brazil", declare for due purpose that the project that originated the study data was not submitted to evaluation by the Ethics Committee, Federal University of Pará. However, we are aware of the content of the National Council for Control of Animal Experimentation (CONCEA; "http://www.mct.gov.br/index.php/ content/view/310553.html") resolutions on animal involvement.

Thus, the authors are fully responsible for the data presented here and are available to answer any questions by the relevant authorities.

Authorization for sample collection

This study was approved by the System for Authorization and Information on Biodiversity from the Chico Mendes Institute for Biodiversity (SISBIO/ICMBIO, protocol 30710-1).

\section{REFERENCES}

BERTO, B.P. et al. Coccidia of New World passerine birds (Aves: Passeriformes): a review of Eimeria Schneider, 1875 and Isospora Schneider, 1881 (Apicomplexa: Eimeriidae). Systematic Parasitology, v. 80, p.159-204, 2011. Available from: $<$ http://link. springer.com/article/10.1007\%2Fs11230-011-9317-8>. Accessed: Aug. 22, 2013. doi: 10.1007/S11230-011-9317-8.

COSTA, I.A. et al. Ocorrência de parasitos gastrintestinais em aves silvestres no município de Seropédica, Rio de Janeiro, Brasil. Ciência Animal Brasileira, v.11, n.4, p.914-922, 2010. Available from: $<$ http://revistas.ufg.emnuvens.com.br/vet/article/view/7164/8369>. Accessed: Mar. 26, 2016. doi: 10.5216/cab.v11i4.7164.

FIGUEROA-LYRA, M. et al. Parásitos gastrointestinales de aves silvestres en cativeiro en el estado de Pernambuco, Brasil. Parasitología latinoamericana, v.57, n.1-2, p.5054, 2002. Available from: <http://dx.doi.org/10.4067/S071777122002000100012>. Accessed: Jan. 12, 2013. doi: 10.4067/ S0717-77122002000100012.

DUSZYNSKI, D.W.; WILBER, P.G. A guideline for the preparation of species descriptions in the Eimeriidae. Journal of Parasitology, v.83, p.333-336, 1997. Available from: <http://digitalcommons. unl.edu/cgi/viewcontent.cgi article $=1164 \&$ context $=$ parasitologyf acpubs $>$. Accessed: Feb. 10, 2009.

GILL, H.; PAPERNA, I. Proliferative visceral Isospora (atoxoplasmose) with morbid impact on the Israel sparrow Passer domesticus biblicus Hartert, 1904. Parasitology Research, v.103, p.493-499, 2008. Available from: <http://link.springer.com/ article/10.1007/s00436-008-0986-4>. Accessed: Mar. 26, 2016

GUIMARÃES, M.B. Passeriformes (pássaro, canário, saíra, gralha). In: CUBAS, Z.S. et al. Tratado de animais silvestres. São Paulo: Roca, 2007. Cap. 22, p. 324-337.

MINISTÉRIO DO MEIO AMBIENTE (MMA). Instrução normativa n. 003, de 26 de maio de 2003. Lista nacional das espécies da fauna brasileira ameaçadas de extinção. Available from: <http://www.mma.gov.br/estruturas/179/ arquivos/179_05122008034002.pdf>. Accessed: Oct. 15, 2013

MONTEIRO, S.G. Técnicas laboratoriais. In: MONTEIRO, S.G. Parasitologia na medicina veterinária. São Paulo: Roca, 2010. Cap.29, p.301-312.

MUSEU PARAENSE EMÍlIO GOELDI (MPEG). Censo da biodiversidade da Amazônia Brasileira. Available from: $<$ http:// www.museu-goeldi.br/censo/>. Accessed: Jan. 19, 2016.

OGLESBEE, B.L. Doenças do trato digestório de aves. In: BIRCHARD, S.J.; SHERDING, R.G. Manual Saunders de clínica de pequenos animais. São Paulo: Roca, 2008. Cap.172, p.1823-1855.

PIACENTINI, V.Q. et al. Annotated checklist of the birds of Brazil by the Brazilian Ornithological Records Committee/ Lista comentada das aves do Brasil pelo Comitê Brasileiro de Registros Ornitológicos. Revista Brasileira de Ornitologia, v.23, n.2, p.91-298, 2015. Online. Available from: <http://www4.museugoeldi.br/revistabrornito/revista/index.php/BJO/issue/view/66>. Accessed: Jan. 18, 2016.

REMSEN, J.V. et al. A classification of the bird species of South America. American Ornithologists Union. Version 19 jan. 2016. Online. Available from: <http://www.museum.lsu.edu/ Remsen/ SACCBaseline.html>. Accessed: Jan. 19, 2016.

SIGRIST, T. Guia de Campo Avis Brasilis - Avifauna Brasileira: pranchas e mapas. São Paulo: Avis Brasilis, 2009. 480p.

VASCONCELOS, M.S.D. et al. Intensidade de infecção por Isospora spp. (Apicomplexa: Eimeriidae) em trinca-ferrosverdadeiros Saltator similis d'Orbigny, Lafresnaye (Passeriformes: Cardinalidae ) mantidos em cativeiro no Município de Valença, Estado do Rio de Janeiro, Brasil. Coccidia, v.1, n.2, p.39-43, 2013. Available from: <http://r1.ufrrj.br/lcc/Coccidia/vol/v1n2/p39-43. pdf $>$. Accessed: Jan. 19, 2016. 